\title{
OS MEMES E SUA APROPRIAÇÃO PELO MARKETING DIGITAL: A EXPERIÊNCIA DA REDE BRASILEIRA DE FAST-FOOD GIRAFFAS
}

\author{
Memes and their appropriation by digital marketing: the \\ experience of Brazilian fast-food chain Giraffas \section{experiencia de la red brasileña de fast-food Giraffas} \\ Los memes y su apropiación por el marketing digital: la
}

\author{
Antonio Hélio Junqueira \\ Pós-doutorando em comunicação e práticas de consumo pela Escola Superior de Propaganda e Marketing \\ (ESPM), doutor em ciências da comunicação pela Escola de Comunicações e Artes da Universidade de São \\ Paulo (ECA/USP), mestre em comunicação e práticas de consumo pela ESPM, pós-graduado em desenvolvi- \\ mento rural e abastecimento alimentar urbano, engenheiro agrônomo, pesquisador e professor da ESPM e da \\ Universidade Anhembi Morumbi. \\ E-mail: helio@hortica.com.br
}

RESUMO Este artigo analisa experiências e abordagens de marketing digital feitas pela rede brasileira de fast-food Giraffas nas quais o uso de memes constituiu a base estratégica da comunicação mercadológica empresarial, buscando avançar no conhecimento científico dos usos, abrangências, potencialidades e limites dos memes para a efetividade e a eficácia da ação promocional de marcas, produtos e serviços no âmbito das novas mídias sociais digitais.

PALAVRAS-CHAVE Comunicação, Consumo, Marketing, Memes, Redes sociais.

ABSTRACT This article aims at examining experiences and approaches of digital marketing of the Brazilian fast-food chain Giraffas in which the use of memes constituted the strategic base of corporate marketing communication, thus allowing us to advance in the scientific knowledge of uses, scopes, potential and limits of memes to the effectiveness and efficiency of promotional campaign of brands, products and services under the new digital social media.

KEYWORDS Communication, Consumption, Marketing, Memes, Social networks.

RESUMEN Este artículo tiene como objetivo examinar experiencias y enfoques relacionados con el marketing digital de la red brasileña de fast-food Giraffas en que el uso de los memes constituye la base estratégica de la comunicación del marketing corporativo, lo que permite avanzar en el conocimiento científico de los usos, alcances, posibilidades y los límites de los memes en la eficacia y eficiencia de campañas de promoción de marcas, productos y servicios bajo los nuevos medios sociales digitales.

PALABRAS CLAVE Comunicación, Consumo, Marketing, Memes, Redes sociales. 


\section{INTRODUÇÃO}

O ambiente digital da Web 2.0, marcado pela crescente disponibilização de novas tecnologias, ferramentas e possibilidades comunicativas, tem permitido a crescente emergência do sujeito criativo, interativo, produtor, recriador e distribuidor de conteúdo: o prosumer. O termo foi introduzido pelo futurologista Alvin Toffler, em 1980, para significar a nova situação possível para o sujeito contemporâneo no contexto das mídias digitais, no qual pode, simultaneamente, ocupar as posições de produtor (producer) e consumidor (consumer) de conteúdos. Tal conceito já havia sido intuído por McLuhan e Nevitt (1972), convictos de que as novas tecnologias eletrônicas viriam alterar substancialmente a situação comunicacional dos frequentadores do ambiente digital. Em 2007, Bruns e Jacobs forjaram, para designar o mesmo conceito, a palavra "produser". No entanto, naquele mesmo ano, Tapscott e Williams (2007) reforçaram a preferência pela adoção do termo "prosumer", por entenderem que este fortalecia a perspectiva da atividade criativa dos sujeitos, no que foram seguidos pelas comunidades técnicas e científicas internacionais.

Nesse contexto midiatizado, uma nova cultura participativa (Jenkins, 2009) vem deslocar de maneira contundente a noção de autoria, viabilizando a convivência de produtos que são continuamente criados e recriados, em uma complexa combinação e alternância de produções profissionais e amadoras, de alta e baixa qualidades técnicas, simultaneamente. Os memes - objeto de investigação desta pesquisa representam uma das mais instigantes possibilidades de interação na dinâmica virtual contemporânea, sendo crescentemente apropriados pela lógica mercadológica de empresas e agências de propaganda e marketing.

Uma importante característica dos memes é sua fundamental propagação viral nas mídias sociais, das quais têm crescentemente migrado para outras esferas e dimensões da vida social contemporânea (Hwang, 2009), especialmente nos campos da propaganda, do marketing e do consumo. $\mathrm{O}$ entendimento desse fenômeno, no conjunto de suas características, potencialidades e limites para a comunicação mercadológica contemporânea, implica a compreensão das imbricações da memória social com a cultura (Pires-Ferreira, 1989; Bergson, 1999; Le Goff, 1992; Dodebei, 2005; Ricouer, 2007), com as possibilidades de agenciamento da afetividade de fãs e com o consumo (Nunes, 2001; Ribeiro, 2015).

\section{MEMÉTICA: CONTROVÉRSIAS EM UM CAMPO EM CONSTRUÇÃO}

A conceituação dos memes procede dos trabalhos originais do evolucionista neodarwinista Richard Dawkins (2001), cujas teses centrais foram lançadas, originalmente em 1976, no último capítulo de seu livro $O$ gene egoísta, em que propõe explicações para a seleção natural, no âmbito da teoria da evolução, a partir da competição entre os genes, entendidos e chamados por ele de replicadores. Tais replicadores podem ser pensados como modelos relativamente estáveis que competem por recursos limitados no ambiente, fazendo cópias de si mesmos. Desta maneira, a luta pela sobrevivência extrapola a competição entre os indivíduos e espécies, para chegar aos genes. 
Dawkins (2001) propõe, a partir dessa perspectiva, o conceito de meme, ao transpor para o campo da Cultura as estratégias reprodutivas encontradas pelos genes, e por ele identificadas no campo da biologia. Para o autor, a palavra "meme" possui a vantagem de ser uma abreviação da palavra grega para imitação ("mimeme") e, ainda, por se aproximar da sonoridade de "gene".

Para grande parte dos autores contemporâneos dedicados ao estudo do meme, ele deve ser compreendido, em sua mais ampla conceituação, como uma ideia repassada adiante, propagando-se por imitação. Para o próprio Dawkins (2001), ideias, slogans, modas do vestuário, modos de fazer objetos utilitários, entre outras práticas humanas, constituem exemplos de memes. Blackmore (2000, p. 6) - considerada, pelo próprio Dawkins e pelo filósofo Dennett (1988), uma das maiores entusiastas e promotoras do tema na atualidade (Leal-Toledo, 2013b) - define como meme "tudo aquilo que se aprendeu de outra pessoa por meio de imitação". Assim como ocorre com os genes, os memes, em seu processo de propagação, também se sujeitam a modificações - verdadeiras mutações - que colaboram para que a ideia se mantenha viva e se adapte progressivamente ao ambiente externo, sempre cambiante, sem perder, contudo, a possibilidade de reconhecimento na memória do público.

Em uma tentativa de sintetizar um conceito para o meme, especialmente no ambiente das mídias sociais, Fontanella (2009a, p. 8) os define como "ideias, brincadeiras, jogos, piadas ou comportamentos que se espalham através de sua replicação de forma viral, caracterizados pela repetição de um modelo formal básico, a partir do qual as pessoas podem produzir diferentes versões do mesmo meme". É interessante observar que, assim, o meme não se confunde com a simples replicação viral de vídeos ou outros produtos midiáticos na Internet, na medida em que, ao longo de seu processo de propagação na rede, surgem constantemente novas versões alteradas da ideia original.

Nos campos da cultura e da comunicação, a competição dos memes se dá, segundo Dawkins (2001), por atenção e retenção, ainda que breve e transitória, no restrito potencial de armazenamento de mensagens e informações na memória e nos cérebros humanos. No caso do ambiente virtual, a luta vincula-se à saturação de estímulos, à qual os frequentadores da Internet são constantemente expostos e que resultam em quantidade já não mais processável de informações.

Nesse contexto, a memética - nome dado à ciência que estuda os memes - passa a ser entendida como capaz de interpretar os fenômenos virais na comunicação digital, inclusive se habilitando à construção e ao desenvolvimento de técnicas capazes de produzir mensagens com maior probabilidade de espalhamento, atraindo sobremaneira os interesses das indústrias de publicidade, propaganda e marketing.

Para Dawkins (2001) - sempre se baseando nos conceitos desenvolvidos para os genes -, o sucesso de um meme, garantido por sua imitação e permanência na cultura, é dado segundo três critérios principais: longevidade (capacidade de permanência na memória coletiva), fecundidade (probabilidade de propagação) e fidelidade de cópia (capacidade de retenção das características do meme original). A pesquisadora brasileira Raquel Recuero (2007 e 2009) acrescenta, ainda, uma quarta dimensão, que se refere ao alcance local ou global dos memes. 
Tentativas de busca de alternativas conceituais e metodológicas para o estudo científico dos memes resultaram na proposição da memesfera, já presente na cibercultura (Pickard, 2008). Trata-se de perspectiva em que se evita a armadilha de enxergar a cultura como um simples amontoado de memes e, ao mesmo tempo, propõe-se o reconhecimento de uma subcultura por eles composta, na qual se estabelecem relações dinâmicas à medida que os sujeitos interagem através deles. Nessa ambiência, os memes não são vistos como "fenômenos culturais aleatórios, e são coletivamente articulados com outras esferas da vida social” (Fontanella, 2009a, p. 12).

A memesfera é concebida a partir da articulação de três dimensões: os artefatos, as práticas e os arranjos sociais. Em relação aos artefatos, compreendem-se a aceleração e a generalização da produção e da circulação dos memes a partir da maior popularização do acesso e uso das TIC e da melhoria tecnológica permanente das ferramentas disponibilizadas para os sujeitos atuantes na Internet (Souza, 2013; Horta, 2015). As práticas, por seu turno, referem-se às interações sociais dos sujeitos a partir, com e através dos memes. Incorporam a dimensão construtiva das subjetividades dos sujeitos na mediação permitida pelo acesso, uso, apropriação e/ou recriação dos memes no interior das práticas culturais já existentes (Livingstone, 1999). Quanto aos arranjos sociais, há de se destacar a articulação da(s) subcultura(s) no entorno de memes específicos, algumas vezes permitindo o estabelecimento de modelos de negócios calcados na exploração comercial, com práticas como aluguel de espaço publicitário em blogs, vendas de produtos temáticos e outras (Pickard, 2008).

Ainda que a memética enfrente problemas e limitações de natureza epistemológica, que frequentemente questionam sua legitimidade no campo científico, muitos pesquisadores contemporâneos consideram que ela não deve ser descartada no estudo dos fenômenos a eles associados no âmbito da Internet (Leal-Toledo, 2009, 2013a, 2013b). Para esses autores, a ideia dos replicadores é considerada atraente e produtiva no estudo do comportamento viral dos memes na rede digital. Torna-se, no ambiente da Internet, viável identificar a unidade replicadora, na forma de um molde comum - às vezes chamado de template - a partir do qual se geram diferentes versões dos memes (Fontanella, 2009a, p. 8). Na Internet, popularizou-se a apropriação da nomenclatura e dos conceitos associados aos memes, permitindo uma utilização coloquial, que abarca um conjunto heterogêneo de fenômenos e práticas (Fontanella, 2009b).

Embora original e historicamente os memes sejam vinculados à produção de elementos toscos, grosseiros, mal-acabados, produzidos com recursos precários, de baixa qualidade estética e considerados de mau gosto, observa-se que, no processo de sua crescente apropriação pela indústria publicitária, os memes passam a angariar recursos sofisticados de produção, acabamento e design, que não modificam, contudo, sua concepção e funcionamento. Para autores como Fontanella (2009a, 2009b), a memesfera identifica-se coerentemente com a cultura digital trash, caracterizada por estética tosca, ironia e paródia (Ribeiro, 2015).

Ainda que notória na prática cotidiana de agências de comunicação, de profissionais e estudantes de marketing e de outros agentes atuantes nas mídias sociais digitais contemporâneas, a memética aplicada ao estudo da apropriação dos memes aos propósitos da propaganda, da publicidade e do marketing, especialmente no ambiente digital, tem 
recebido pouca atenção acadêmica. De fato, a produção científica centrada nessa temática, especialmente no Brasil, é ainda limitada e pouco abrangente, embora sinalizada internacionalmente como abordagem produtiva e promissora por autores como Dugatkin (2000), Norman (2004) e Murray, Manrai \& Manrai (2014).

Esta pesquisa vem, nesse sentido, buscar contribuir para a superação ou diminuição de tal lacuna, avançando na sistematização crítica do conhecimento acumulado na exploração de temáticas afins e no estudo da produtividade dos pressupostos conceituais e teóricos da memética para a análise de fenômenos frequentes e relevantes para a propaganda, publicidade e marketing contemporâneos.

\section{REDE GIRAFFAS: APROPRIAÇÃO MERCADOLÓGIA DOS MEMES}

A Giraffas é uma rede brasileira de fast-food, fundada em Brasília, em 1981, mantendo até hoje capital nacional integral. Seu nome é uma referência bem-humorada às discotecas Hippopotamus e Crocodilos, criadas naquele período pelo empresário da noite Ricardo Amaral, e demarcava, com ironia, o isolamento de Brasília do circuito ou eixo cultural Rio-São Paulo. Segundo a agência Rato, responsável pela criação da logomarca da empresa, a grafia do nome com dois efes ("ff") originou-se da escrita em latim do nome do animal (giraffa), mas pode ser lida também como mais uma referência ao nome da casa noturna Hippopotamus, que também trazia a duplicação da letra e a reprodução do nome científico em latim da espécie.

Um dos mais significativos diferenciais dessa rede foi sua profunda incorporação do cardápio trivial da cozinha brasileira, com alimentos simples e corriqueiros como feijão, farofa e ovo frito, em combinação com diferentes tipos de carnes grelhadas e saladas simples.

A partir de 1991, depois de ter sido vendida por seus fundadores, a empresa adotou o sistema de franquias. Rapidamente se espalhou por todo o país, tendo atingido em 2016 mais de 400 unidades em funcionamento, além da incorporação do serviço delivery. Internacionalizou-se em 2011, com a abertura do primeiro restaurante em Miami (EUA) e, logo em seguida, de outro no Paraguai.

A companhia vem adotando agressiva estratégia de marketing, centrada nas mídias digitais, especialmente em redes sociais como o Facebook, desde 2009 e 2010. Inicialmente, suas postagens centraramse na exploração de imagens de girafas nas mais diferentes situações. Porém, mais recentemente, a empresa entrou de vez na exploração dos memes, adotando como elemento de diálogo a mascote da rede uma girafa boneco no formato de fantoche de mão - que se traveste dos personagens popularmente mais memetizados a cada momento, que tanto pode ser a funcionária pública da Assembleia Legislativa de Goiás fugindo da repórter que a interpela sobre irregularidades na assinatura de ponto ("Senhora? Senhora?"), como a estapafúrdia troca entre as Misses Universo recém-coroadas, jogadores, artistas, ou os próprios memes ("o vestido que muda de cor", as "selfies" e os "nudes", por exemplo).

A exploração dos memes pelo marketing digital da rede Giraffas tem sido apontado, por profissionais e especialistas, como um dos mais bemsucedidos casos setoriais na contemporaneidade brasileira, trazendo atualidade, humor e forte engajamento dos fãs da marca. Entre as 
iniciativas de maior sucesso, até 22 de abril de 2016, destacavamse: a) associação com o Burger King norte-americano na campanha pelo Dia Mundial da Paz de 2015 (setembro de 2015: 69 mil curtidas, 3.352 compartilhamentos e 3.093 comentários); "Senhora? Senhora?" (setembro de 2015: 39 mil curtidas, 4.373 compartilhamentos e 3.093 comentários); "Eu voto sim!" (abril de 2016: 17 mil curtidas, 763 compartilhamentos e 360 comentários); e "Bela, recatada e do lar" (abril de 2016: 1,7 mil curtidas, 363 compartilhamentos e 110 comentários).

\section{METODOLOGIA}

Para a consecução dos objetivos propostos, a pesquisa utilizou abordagens multimetodológicas, baseadas na coleta e análise sistemática de textos publicitários publicados pela própria empresa anunciante em sua fanpage no Facebook. ${ }^{1}$ Elegeram-se, para análise, duas campanhas de natureza memética, considerando atualidade, abrangência e relevância dos temas correlacionados. A primeira delas foi "Eu voto sim", decorrente dos infindáveis pronunciamentos dos parlamentares no plenário da Câmara dos Deputados, em 17 de abril de 2016, que se estenderam por 6 horas e 2 minutos, em sessão total de 9 horas e 47 minutos, por ocasião da votação para autorização do processo de impeachment da presidente Dilma Rousseff. A segunda foi "Bela, recatada e do lar”, expressão imediatamente viralizada nas redes sociais digitais a partir da publicação de matéria assinada pela jornalista Juliana Linhares (2016) sobre o perfil de Marcela Temer, esposa do vicepresidente do Brasil, Michel Temer.

No caso da primeira campanha, a sátira, a graça e a paródia memetizadas nasceram do caráter risível, popularesco e carnavalesco das manifestações públicas dos parlamentares previamente a seus respectivos votos e que enumeraram as mais estapafúrdias justificativas de suas opções favoráveis ou não ao impeachment. No segundo caso, a expressão cunhada no título da matéria desdobrou-se em versões cômicas e provocativas ("Fera, empoderada e do bar", "Livre, desbocada e do mar", "Belos, desbocados e do bar", entre inúmeras outras) e de imagens que, pela obviedade de sua inversão simbólica, traduziam a denúncia da ideologia machista, arcaica e patriarcal da visão sobre o papel socioeconômico, cultural e político da mulher na sociedade brasileira contemporânea, conforme inserida na expressão memetizada. Comentários reativos, produções textuais criativas e interações comunicativas do público-alvo em relação aos conteúdos propostos pelo marketing digital das campanhas publicitárias analisadas também compuseram o corpus de análise da pesquisa.

Para a análise crítica dos conteúdos selecionados, foram aplicados os princípios teórico-metodológicos da análise do discurso de linha francesa (Gregolin, 2003; Fairclough, 2008).

\section{DISCUSSÃO}

A apropriação dos memes pelas empresas em campanhas de marketing digital busca explorar, nos limites da imitação e da paródia -

1. https://www.facebook.com/redegiraffas/?fref=ts 
formas carnavalizadas genéricas nas quais se funda -, as múltiplas vozes do reforço, da contradição e/ou da recriação dos dizeres e sentidos de que os textos são portadores (Bakhtin, 2008). A partir dessas operações comunicativas, visa angariar e sustentar envolvimento, engajamento e simpatia dos consumidores, que venham potencialmente resultar, por sua vez, em posicionamento, memorização e construção de referências afetivas e espirituais favoráveis à marca (Kotler; Kartajaya; Setiawan, 2010). Partindo de reconstruções, remixagens e reconstituições criativas de eventos cotidianos existentes e conhecidos, tais iniciativas necessitam mobilizar repertórios culturais dos receptores/consumidores para produzir resultados surpreendentes, bem-humorados, divertidos, lúdicos e inesperados, pela estranheza que contêm (Knobel; Lankshear, 2007).

A ação comunicativa dos memes decorre fundamentalmente de sua intertextualidade e do pronto e reconhecível estabelecimento de conexões com o real-histórico, lugar onde se exploram as ambiguidades, polifonias e polivalências sígnicas possíveis dos textos meméticos eleitos. Para Ribeiro et al. (2015, p. 249), "memes são um meio de transformar textos culturais estabelecidos em novos, para negociar o valor das diversas identidades e se envolver em argumentos não convencionais sobre eventos cotidianos”. A interpretação do meme exige cumplicidade e competência cultural dos receptores/consumidores para que se identifiquem, compreendam e decodifiquem as sutilezas das inversões de sentidos sígnicos propostos.
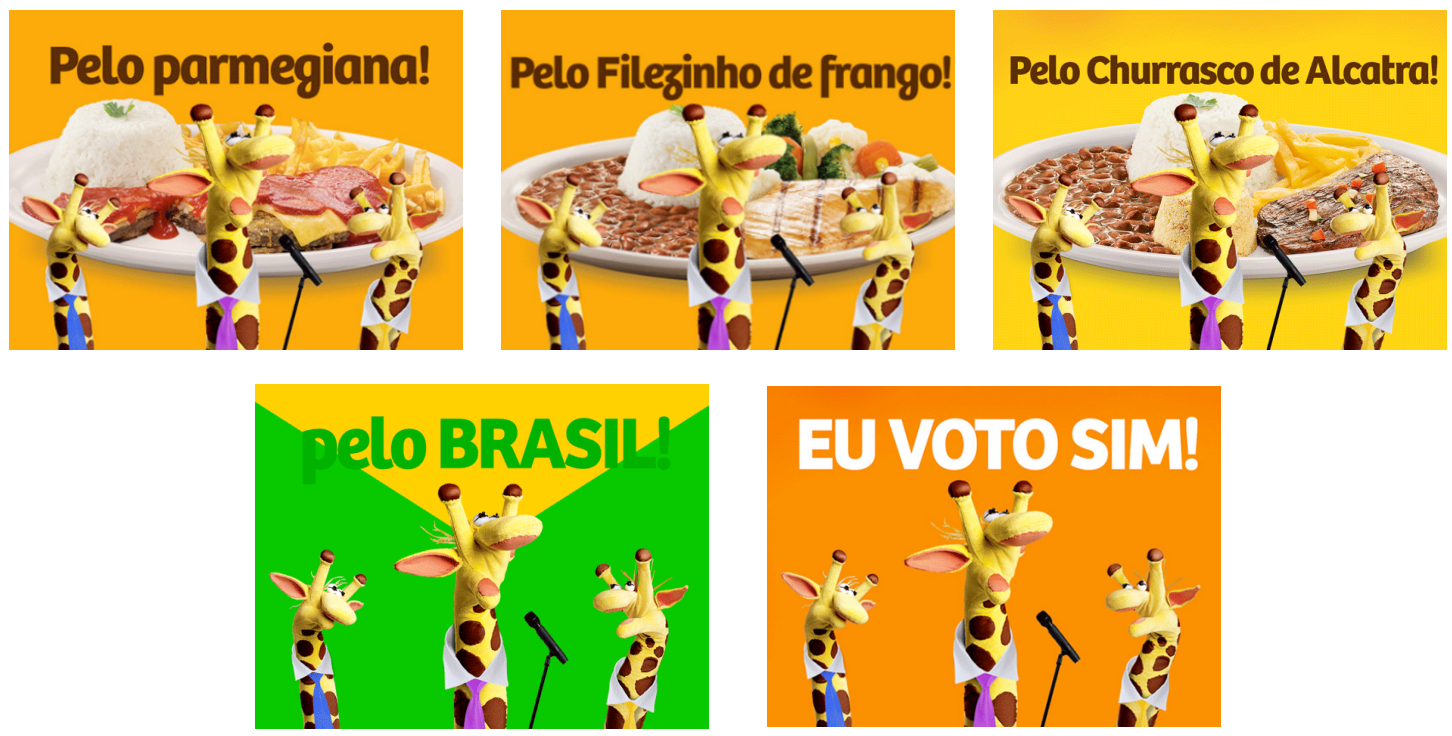

Figura 1. Campanha "Eu voto sim!", veiculada a partir da votação da autorização do processo de impeachment da presidente Dilma Rousseff, em 17 de abril de 2016.

Nos dois exemplos de ações de marketing postas em circulação pela rede Giraffas eleitos para análise neste estudo, podem-se constatar discursos paródicos, nos quais há apropriação do discurso dominante veiculado pela grande mídia e decorrente de expressões de importantes setores da representação do poder público constituído no Brasil. Observa-se, em operação, a recontextualização dos discursos, que, pela manutenção das referências, mas com a alteração ambivalente das configurações originais, permite o afloramento da criticidade, do escarnecimento e do riso, ressaltando, ao mesmo tempo, a relevância social do discurso parodiado (Bergson, 2007). Os dois casos foram 
veiculados em GIF (graphics interchange format) animados, compostos por seis e cinco imagens sequenciais, respectivamente. A ação comunicativa completa-se com a criação e publicação das hashtags correspondentes: \#NãoVaiterFome (em nítida referência ao jargão das manifestações públicas contra o impeachment da presidente "Não vai ter golpe") e "\#belarecatadaedolar".
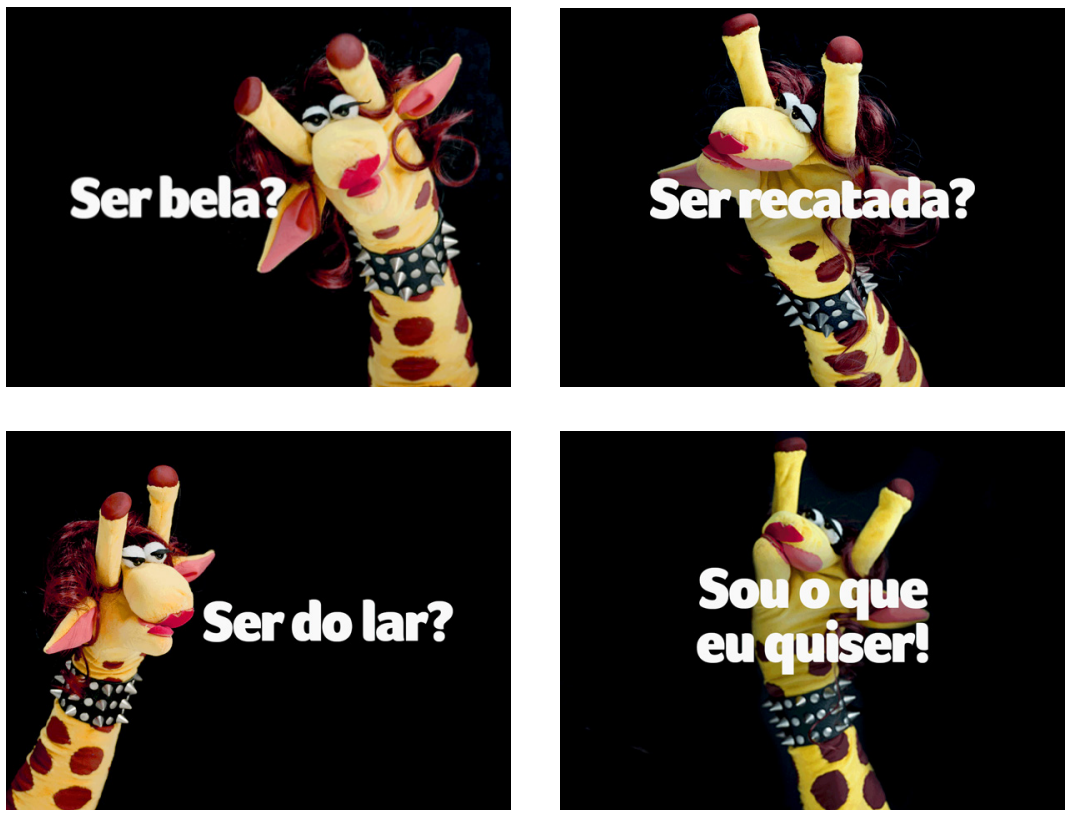

Figura 2. Campanha "Bela, recatada e do lar", veiculada a partir da publicação de matéria da revista Veja, abril de 2016

Em ambos os casos, a personagem mascote da Giraffas posicionase a partir de referências a posturas consideradas politicamente incorretas e embaraçosas adotadas por autoridades e personalidades públicas nacionais e fartamente distribuídas nas e pelas mídias de massa, especialmente a televisão e as principais revistas de circulação semanal. A comicidade, nesses casos, decorre tanto da incorreção política dos enunciados e contextos originais quanto da reapropriação cínica e invertida dos discursos sob a perspectiva publicitária dos produtos e ícones da própria empresa anunciante.

O inusitado das campanhas extrai graça e riso, também, pelo fato de, em certa medida, apaziguar ânimos e neutralizar o mal-estar público decorrentes da constatação do ridículo e do desvio do comportamento normalmente aguardado de autoridades e personalidades públicas nas situações representadas.

Assim como seu surgimento, também a durabilidade de um meme é imprevisível. As possibilidades de uso e incorporação pelo discurso publicitário decorrem ora da potencial vinculação positiva da imagem da marca a um valor ou causa social - combate às discriminações de gênero, etnias, orientações políticas ou sexuais, apoio a causas ambientalistas, entre outras - ora do agenciamento das memórias afetivas dos consumidores e fãs. Frente à imprevisibilidade da duração e à velocidade da viralização digital, a produção publicitária vinculada à exploração dos memes é fortemente desafiada a compreender, prever e aproveitar oportuna e tempestivamente o fenômeno memético a favor de suas campanhas. Tal fato demanda monitoramento e gerenciamento 
especializados das mídias sociais digitais, constituição de equipes profissionais capacitadas, alto poder para tomada de decisões em relação à avaliação estratégica das oportunidades de entrada e saída na veiculação de campanhas baseadas em conteúdo memético e que, eventualmente, possam constituir necessidade de gerenciamento de crises.

Nas campanhas analisadas, pode-se observar as majoritárias, entusiasmadas e crescentes aprovação, adesão e engajamento por parte de consumidores e fãs da marca, expressas repetidamente em comentários como: "as renovações das propagandas do Giraffas estão demais!!!", "Preciso dizer que, ao ver a inovação que o Giraffas deu em suas propagandas no FB, me tornei fã, sim!”, "É o melhor marketing dos tempos atuais!!!", "Uma propaganda mais divertida do que a outra. Show...", "a irreverência e os posicionamentos do marketing do Giraffas são sensacionais”, "Vocês são demais! Melhor página!”, “A Giraffas é sempre muito antenada com o que tá rolando", "Você é demais, Girafinha, tá no meu coração...”, “Quero levá-las para o meu lar”, “Cada dia mais apaixonada nessas girafinhas! Somos o que quisermos”. A interação favorável com o público é constatável, também, pela proliferação dos emoticons: heart (coração), smile (sorriso), applause (aplauso), kiss (beijo) e wink (piscadela).

O fenômeno observado corrobora o entendimento de que o uso de memes de alcance local - em contraposição aos de abrangência global - favorece o estreitamento de laços e as interações sociais (Recuero, 2007), pois possuem características agregadoras, capazes de reduzir distâncias e propiciar a criação de grupos e comunidades, inclusive de fãs. São memes considerados de grande impacto em redes sociais, aptos à geração de forte retorno, interação e engajamento de consumidores.

A aquiescência, o respeito e a admiração pelas campanhas publicitárias evidenciaram ser provenientes, em grande medida, de profissionais, pesquisadores e estudantes de marketing, o que atesta a relevância e o senso de oportunidade da exploração dos memes na construção do discurso publicitário brasileiro contemporâneo. Vejamse os excertos selecionados a seguir: "Giraffas, eu e meus amigos fizemos um artigo sobre o marketing de relacionamento de vocês", "Eu quero trabalhar no marketing do Giraffas!!!!! Seria o meu sonho!", "Melhor social media do Brasil", "Sou social media e pesquisador, e tenho que dar parabéns ao Giraffas, a página da rede é uma das melhores que tenho acompanhado ultimamente...", "Um sonho: trabalhar na área de marketing do Giraffas", "É por essa e outra que eu sigo a página do Giraffas", "Muito amor pelo marketing de vocês", "Adorei essas propagandas!!! Morro de rir kkkkk...", "Sério cara. Que social media é esse?”, "Hahahaha Social Media me manda seu cv, cara!”, "Já podem aumentar o salário do social media”, "Giraffas, melhor rede com comerciais épicos”, "Marketing do Giraffas está duplamente de parabéns, sempre atuando diante dos principais temas do país de modo interessante".

A fruição aprovativa das campanhas pelos próprios especialistas (Giddens, 1991) pode ser constatada, ainda, na pronta apropriação publicitária do mito - no sentido proposto pela semiótica barthesiana (Barthes, 1972) - em prol da construção de novos contextos destinados a encantamento e persuasão de consumidores, a partir da ressignificação de elementos e discursos do repertório coletivo: "Como vocês tem essa 
capacidade de mitar como sempre?”, "VCS MITÃO DEMAIS...”, “Mais uma vez eles estão mitando. Né não?”.

Na manifestação afetuosamente impactada dos fãs, pode-se acompanhar a expressão crescente do engajamento favorável à penetração e expansão da marca, sinalizando para a eficácia da campanha publicitária: "eu tenho que ir comer no Giraffas só por causa da página de vocês!”, “Manda um lanche pra gente, já que aqui na cidade não tem nenhum Giraffas", "Vem pra Blumenau, por favor!”, "Uma pena que fechou aqui em Boa Vista", "O que aconteceu com as lojas de Sorocaba?”, "Demais! Precisamos de um Giraffas em Umuarama”, "Giraffas, vocês poderiam inaugurar uma rede em Guaxupé-MG (aonde eu moro), né?!”, “Tá fazendo falta no North Shopping Jóquei em Fortaleza”, "Pela volta do Giraffas a Boa Vista (RR), eu voto SIM!!!”, "Rede Giraffas vem para Birigui SP. Aqui vocês vão fazer sucesso!”, "Depois dessa bateu uma vontade de ir no giraffas bater uma à parmegiana com fritas + suco + sorvetinho. Bora?”, "Ah, tenho uma história de amor pelo strogonoff de frango de vcs! o melhor!", "Giraffas, pela volta do Molho de Ervas com Manteiga!! Eu voto Sim!”, "Por mais franquias do Giraffas... Voto SIM", "Pelo almoço com gostinho Brasileiro eu VOTO GIRAFFAS", "Pela excelente comida e pela ótima equipe, eu voto sim p/ o Giraffas", "Vamos trocar todos os nossos deputados por girafinhas lindas? Eu digo sim!”.

Por outro lado, memes de abrangência local podem potencialmente também se transformar em elementos de ruptura e conflito (Recuero, 2007). Nos casos estudados, foi possível observar grande cuidado e habilidade da equipe de marketing da Giraffas em contornar tais ameaças, com vistas a evitar que o fenômeno desestabilizasse a presença digital da empresa e a interação com consumidores e fãs. Frente a manifestações como as que a seguir são relatadas, a equipe de marketing da rede optou por silenciamento ou, em raros momentos, reafirmação da simples vontade de "causar zuêra", em vez de assumir quaisquer posições ideológicas. Vejam-se os excertos: "Apoio discreto ao impeachment ou é impressão minha?”; resposta: "Impressão sua, estamos apenas zuando a maneira como os deputados deram seus votos”.

Exemplos de expressões portadoras de conflitos potenciais encontrados foram: "Sou bela recatada e do lar e sou feliz assim, essa polêmica toda como se fosse ser ruim assim", "Fazer piada com um dos momentos mais tristes da jovem república é o fim da picada. Sabe o que são 300 deputados dizendo que votam sim para um golpe 'Por causa da minha família'?”, “O Brasil não é sério, as empresas aqui são como a Vale no caso do Rio Doce: Irresponsáveis, alienantes...”, "Não consigo vê graça, fazer graça de um momento político tão tenso para nossa população.”

\section{CONSIDERAÇÕES FINAIS E SUGESTÕES PARA NOVOS ESTUDOS}

Este estudo teve por objetivo identificar, resgatar, analisar e interpretar, no espaço do marketing digital brasileiro recente, investidas da rede brasileira de fast-food Giraffas na exploração de memes, discutindo pontos e características eleitos para a abordagem mercadológica, bem como avaliar reações do público receptor a essas mensagens propagandísticas e promocionais. Seus resultados permitem 
observar a eficácia das iniciativas, bem como encontrar e apontar elementos que possam servir de norteadores críticos para outras empresas ou profissionais do marketing interessados na exploração do potencial dos memes na promoção comercial de marcas, produtos e serviços.

Dessa forma, a pesquisa corrobora a pertinência do objeto ao campo de preocupações do marketing brasileiro contemporâneo, sinalizando para a oportunidade e a necessidade de ampliação e aprofundamento do tema em novos estudos, especialmente contemplando abordagens que levem em consideração a relevância e a eficácia promocional e mercadológica do agenciamento dos memes de afeto, solicitados e mobilizados para contribuir no alinhamento proativo dos fãs no apoio a relançamentos, remakes e reforços promocionais, ou na apropriação de memórias sociais afetivas em prol de lançamentos de novas marcas, produtos ou serviços.

\section{REFERÊNCIAS}

BAKHTIN, M. A cultura popular na Idade Média e no Renascimento: o contexto de François Rabelais. São Paulo: Hucitec, 2008.

BARTHES, R. Mitologias. São Paulo: Difusão Europeia do Livro, 1972.

BERGSON, H. O riso: ensaio sobre a significação da comicidade. São Paulo: Martins Fontes, 2007.

Matéria e memória: ensaio da relação do corpo com o espírito. São Paulo: Martins Fontes, 1999.

BLACKMORE, S. The meme machine. Oxford: Oxford University Press, 2000.

BRUNS, A.; JACOBS, J. Uses of blogs. Nova York: Peter Lang, 2007.

DAWKINS, R. O gene egoísta. Belo Horizonte: Itatiaia, 2001.

DENNETT, D. C. A perigosa ideia de Darwin. Rio de Janeiro: Rocco, 1998.

DODEBEI, V. O que é memória social?. Rio de Janeiro: Contracapa/PPG-MS da UFERJ, 2005.

DUGATKIN, L. A. The imitation factor: evolution beyond the gene. Nova York: The Free Press, 2000

FAIRCLOUGH, N. Discurso e mudança social. Brasília: Editora da UnB, 2008.

FONTANELLA, F. O que é um meme?: proposta para uma problemática da memesfera. In: SIMPÓSIO NACIONAL ABCIBER, 3, ESPM, São Paulo, 16-18 de novembro de 2009. Anais. São Paulo: ESPM, 2009a.

O que vem de baixo nos atinge: intertextualidade, reconhecimento e prazer na cultura digital trash. In: INTERCOM - CONGRESSO BRASILEIRO DE CIENNCIAS DA COMUNICAÇÃO, 32, Curitiba, 2009. Anais. Curitiba: 2009b.

GIDDENS, A. As consequências da modernidade. São Paulo: Editora Unesp, 1991.

GREGOLIN, M. R. Sentido, sujeito e memória: com o que sonha nossa vã autoria?. In: GREGOLIN, M. R.; BARONAS, R. (Org.). Análise do discurso: as materialidades do sentido. São Carlos: Claracruz, 2003. p. 47-60.

HORTA, N. B. O meme como linguagem da Internet: uma perspectiva semiótica. 2015. Dissertação (Mestrado em Comunicação) - Universidade de Brasília, Brasília, 2015.

HWANG, T. The LOLCat-hedral and the bizarre: a memescape manifesto. Cambridge: Berkman Klein Center for Internet and Society at Harvard University Press, 2009. Disponível em: http://bit.ly/2fOpG00. Acesso em: 16 out. 2016. 
KNOBEL, M.; LANKSHEAR, C. Online memes, affinities and cultural production. In: A new literacies sampler. Nova York: Lang Press, 2007.

KOTLER, P.; KARTAJAYA, H.; SETIAWAN, I. Marketing 3.0: as forças que estão definindo o novo marketing centrado no ser humano. Rio de Janeiro: Elsevier, 2010.

LEAL-TOLEDO, G. Em busca de uma fundamentação para a memética. Trans/Form/Ação, Marília, v. 36, n. 1, p. 187-210, jan./abr. 2013 a.

Uma crítica à memética de Susan Blackmore. Revista de Filosofia Aurora, Curitiba, v. 25, n. 36, p. 179-195, jan./jun. 2013b.

Controvérsias meméticas: a ciência dos memes e o darwinismo universal em Dawkins, Dennet e Balckmore. 2009. Tese (Doutorado em Filosofia), Pontifícia Universidade Católica do Rio de Janeiro, Rio de Janeiro, 2009.

LE GOFF, J. História e memória. Campinas: Editora da Unicamp, 1992.

LINHARES, J. Bela, recatada e do lar. Veja, edição especial, n. 2.474, ano 49, abril de 2016, p. 25-26.

LIVINGSTONE, S. New media, New audiences?. New Media \& Society, Londres, n. 1, p. 5966, 1999.

MCLUHAN, M.; NEVITT, B. Take today: the executive as dropout. Toronto: Longman Canada, 1972.

MURRAY, N.; MANRAI, A.; MANRAI, L. Memes, memetics and marketing. In: MOUTINHO, L.; BIGNÉ, E.; MANRAI, A. K. (Org.). The Routledge companion to the future of marketing. Nova York: Routledge, 2014. p. 331-347.

NORMAN, D. A. Emotional design: why we love (or hate) everyday things. Nova York: Basic Books, 2004

NUNES, M. R. F. A memória na mídia: a evolução dos memes de afeto. São Paulo: Annablume, 2001

PICKARD, A. ROFLCon: life is a LOLercoaste. The Guardian Technology Blog, 2008. Disponível em: http://bit.ly/2fzPuN6. Acesso em: 16 out. 2016.

PIRES-FERREIRA, J. Cultura é memória. Revista da USP, São Paulo, n. 24, mar./maio 1989. RECUERO, R. C. Redes sociais na Internet. Porto Alegre: Sulina, 2009.

Memes em weblogs: proposta de uma taxonomia - conexões nas redes midiáticas. Revista Famecos, Porto Alegre, n. 32, p. 23-31, abr. 2007.

RIBEIRO, A. P. G. et al. O riso e a paródia na ficção televisiva transmídia: os vilões em memes da Internet. In: LOPES, M. I. V. (Org.). Por uma teoria de fãs da ficção televisiva brasileira. Porto Alegre: Sulina, 2015. p. 239-280.

RICOUER, P. A memória, a história, o esquecimento. Campinas: Editora da Unicamp, 2007.

SOUZA, C. F. Memes: formações discursivas que ecoam no ciberespaço. Vértices, Campos dos Goytacazes, v. 15, n. 1, p. 127-148, 2013.

TAPSCOTT, D.; WILLIAMS, A. Wikinomics: como a colaboração em massa pode mudar o seu negócio. Rio de Janeiro: Nova Fronteira, 2007.

TOFFLER, A. La tercera ola. Cidade do México: Edivisión, 1981. 